\title{
Protection of the Rights of the Victims of Human Trafficking: Has Malaysia Done Enough?
}

\author{
Rohaida Nordin \\ Faculty of Law, National University of Malaysia, Malaysia \\ Email: rohaidanordin@ukm.edu.my \\ Renuka a/p Jeyabalan \\ Faculty of Law, National University of Malaysia, Malaysia \\ Email: jernuka_188racketmail@yahoo.com
}

\begin{abstract}
Human trafficking is a grave threat to human rights. Statistic shows that yearly almost thousands of men, women, and children grieve in the hand of traffickers as human trafficking victims, in their own countries or abroad. Thus, there is a need for Malaysia to take necessary steps to combat human trafficking and at the same time to provide effective protection for victims of human trafficking as enacted under the Malaysian Anti-Trafficking in Persons and Anti-Smuggling of Migrants Act 2007 (ATIPSOM 2007). The first part of this research examines the international law standards on human rights protection of the victim of human trafficking while the second part analyses any legal and policy measures adopted within the Malaysian context. In this analysis, attention will be made on numerous protection mechanisms such as provision for a shelter, or a place of refuge, appointment of Protection Officers, medical treatment, right to work and safe repatriation. This research further examines and assesses the adequacy and effectiveness of the current measures and laws especially in terms of their enforcement by the relevant enforcement bodies. Analysis on the existing legal framework within other ASEAN States, including Indonesia, is used as a foundation to suggest best practices to the Malaysian government. This research concludes with preliminary solutions to address the problems and challenges within the existing legal framework in Malaysia with the ultimate aim at providing better protection for the victims of human trafficking.
\end{abstract}

Keywords: Human rights, trafficking in person, victims, Malaysia, ATIPSOM

\section{INTRODUCTION}

Human trafficking is not only serious offence but also leads to grave violation of human rights. Yearly, thousands of people fall into the hands of traffickers either in their own countries or abroad. Around the world, the crime rate of human trafficking has increased drastically. Almost every country affected is a country of origin, transit, or destination of this crime. ${ }^{1}$ In May 2015 for example, the news of a

1 Protocol to Prevent, Supress and Punish Trafficking in Persons, Especially Women and Children, supplementing The United Nations Convention Against Transnational Organized Crime, 2000. 
mass grave of 139 bodies in Wang Kelian, a region along the Thailand-Malaysia border shocked the world. These bodies were believed to be victims of human trafficking and there were allegations that the heavily timbered Thailand - Malaysia border has been a transfer point for smugglers and traffickers in transporting victims to Southeast Asia. Trafficking victims were held for ransom, were subjected to torture, ill-treated and starved. After the discovery of these bodies, no Malaysian or officers from the relevant Malaysian enforcement agencies were charged. ${ }^{2}$ This individual case showscases a need for Malaysia to take the necessary step to combat human trafficking and at the same time to provide effective protection for victims of human trafficking.

This article examines and assesses the adequacy and effectiveness of numerous victims' protection mechanisms such as provsions for shelter, appointments of Protection Officers, medical treatment, right to work, freedom of movement, and safe repatriation. The scope of the paper is to determine if Malaysia has done enough to protect victims of human trafficking. In such assessment, reference is made to relevant laws, policies, and Court cases.

\section{MALAYSIAN INTERNATIONAL AND DOMESTIC COMMITMENT}

Malaysia is a State Party to the Protocol to Prevent, Suppress and Punish Trafficking in Persons, especially Women and Children supplementing the United Nations Convention against Transnational Organized Crime (the TIP Protocol) and human rights instruments, the Convention on the Elimination of All Forms of Discrimination against Women (CEDAW) and the Convention on the Rights of the Child (CRC). Article 6 of CEDAW provides that States Parties shall take all appropriate measures, including legislation, to suppress all forms of gender based trafficking and exploitation. ${ }^{3}$ Article 35 of the CRC provides that States Parties shall take all appropriate national, bilateral and multilateral measures to prevent the abduction of, the sale of or traffic in children for any purpose or in any form. ${ }^{4}$ These two provisions clearly demand that children and women shall be protected from human trafficking and as a State Party. Indeedn, Malaysia has legal obligation to provide for such protection.

At the regional level, Malaysia is a member of the Association of Southeast Asian Nations (ASEAN). Malaysia is also a party to binding and non-binding instruments such as the ASEAN Human Rights Declaration and the Treaty on Mutual Legal Assistance in Criminal Matters. Malaysia also is a supporter of the ASEAN Commission on the Rights of Women and Children and the ASEAN Committee on the Implementation of the ASEAN Declaration on the Promotion and Protection of the Rights of Migrant Workers. Finally, Malaysia is a member of

2 James Nayagam. "Human trafficking - an analysis of issues", (14 July 2016), online: http://www.freemalaysiatoday.com/category/opinion/comment/2016/07/14/human-traffickingan-analysis-of-issues.

3 Convention on the Elimination of All Forms of Discrimination against Women, 1979.

4 Convention on the Rights of the Child, 1989. 
the Bali Process on People Smuggling, Trafficking in Persons and Related Transnational Crime.

In 2007, the Government of Malaysia in combating human trafficking has enacted the Anti-Trafficking in Persons and Anti-Smuggling of Migrants (ATIPSOM) and amended few provisions in the year of 2010 and 2015. Part V of the Act, specifically provides for care and protection of trafficked persons. There are also provisions relating to protection orders, whereby a person is placed at a shelter home and for the medical treatment and hospitalization of trafficked persons. A new provision, added by the 2015 amendment legislation, enables trafficked persons to be given permission by anti-trafficking council (MAPO) to move freely or to be employed outside the place of refuge

Additionally, the Government of Malaysia in March 2018 took another proactive move by establishing an anti-trafficking court in order to expedite the hearing of trafficking cases in the State of Selangor, which statistically had the highest number of reported in person trafficking cases. The court in its first month successfully expedited the hearing of the 12 trafficking cases in an existing court by setting aside a few hours a week for senior, experienced judges to focus on trafficking cases. It gave opportunity for the prosecutors to engage with victims at least two weeks prior to trial to better understand and address victims properly.

The Trafficking of Persons (TIP) Report is a report issued by the US Department of State on a yearly basis. This report is a tool for engaging foreign government on human trafficking. TIP Report lays out possible steps each government can take to protect human trafficking victims, prevent human trafficking and prosecute traffickers. The TIP Report for 2018 shows that Malaysia was downgraded to Tier 2 Watch List compared to previous year which listed in Tier 2. Between 2006 and 2018 Malaysia had been classified on the Tier 2 Watch List nine times and the report specified that the Government of Malaysia had failed in curbing human trafficking. ${ }^{5}$ As per the report, Malaysia still does not meet the standards. The Malaysian government's victim protection efforts remained largely inadequate and the government identified fewer victims than the previous year."

The the TIP Report 2018 shows that there is a need for Malaysia to enhance its law on anti-trafficking in persons and related procedures to combat human trafficking especially implementing effective protection for human trafficking victims. With this context in mind, it is timely for this research to examine whether Malaysia has done enough. Specifically, attention will be given to protection mechanisms such as: the provision for a shelter or a place of refuge; appointment of Protection Officers; right for medical treatment; right to work; freedom of movement; and safe repatriation. For each mechanism, this article analyses Malaysia's success in combatting human trafficking and protecting victims by

5 Janita Kan. "Malaysia Commits to Combating Human Trafficking after US Report", (2 July 2018), online: https://www.theepochtimes.com/malaysia-commits-to-combating-humantrafficking -after-us-report_2580760.html.

6 Trafficking In Persons Report, Malaysia, (2015), online: http://www.state.gov/j/tip/rls/tiprpt/2015 /243366.htm. 
reviewing its compliance with international laws, regional laws, and the relevant case law.

\section{SHELTER OR PLACE OF REFUGE}

Proper care and assistance for an identified trafficking victim is a dynamic human rights issue. A country either being transit or receiver of trafficking victim has a responsibility to provide a shelter or place of refuge for trafficking victims. Part Two of the TIP Protocol specifically drafted provisions on protections for human trafficking victims. Article 6(2) of the TIP Protocol deals with the assistance to and protection of victim of trafficking in persons. ${ }^{7}$ Furthermore, the protocol outlines that the state parties also shall consider implementing measures to provide for the physical and social recovery of victims of trafficking in persons. Importantly the State Parties with the co-operation of the non-governmental organisation shall provide the victims appropriate housing, counselling and information, with regard to their legal rights, in a language that the trafficking survivorscan understand. The State Parties shall also provide medical, psychological, material assistance, employment, educational, and training opportunities to the victims of trafficking in persons. Article 6(4) further provides that each State Party shall take into account, in applying the provisions of this Article, the age, gender and special needs of victims of trafficking in persons, with an emphasis on $i$ the special needs of children. ${ }^{8}$ This could include appropriate housing, education, and care. Additionally, a State Party shall endeavour to provide for the physical safety of victims of trafficking in persons while they are within its territory. ${ }^{9}$

Over the years, Malaysia has increased efforts to improve its victim protection system. Under the current anti-trafficking law ATIPSOM, Malaysia accommodated the victims under government facilities for 21 days-interim protection orders for suspected victims and 90 days protection orders for certified victims. Section 42 of ATIPSOM provides that a Minister may use "Gazette," or a tool to formally notify his/her consitutions of governmal issues, to declare any house, building or place that can be a place of refuge for the care and protection of trafficked person. ${ }^{10}$ The Minister also may direct the separation of different categories of trafficked person among others according to trafficked persons age, victim and gender. As of 2017, the Government of Malaysia together with non-governmental organisation, has built ten shelters for the victims. The Ministry of Women, Family, and Community Development maintained seven facilities specifically to house trafficking victims:

7 Protocol to Prevent, Supress and Punish Trafficking in Persons, Especially Women and Children, supplementing The United Nations Convention Against Transnational Organized Crime, 2000, Article 6(2).

8 Protocol to Prevent, Supress and Punish Trafficking in Persons, Especially Women and Children, supplementing The United Nations Convention Against Transnational Organized Crime, 2000, Articlw 6(4).

9 Protocol to Prevent, Supress and Punish Trafficking in Persons, Especially Women and Children, supplementing The United Nations Convention Against Transnational Organized Crime, 2000, Article 6(5).

10 Anti-Trafficking In Persons and Anti-Smuggling of Migrants Act, 2007, s. 42. 
four for women, one for men, and two for children. Another three shelters for victims run by non-governmental organisation are based in Kuala Lumpur, Sabah, and Penang, respectively." In 2015, the Special Rapporteur of United Nations Human Rights Council included in a report that he was impressed by the standard of the 3 shelters provided by the government of Malaysia's for victim of trafficking. The report described these shelters as modern, clean, and equipped with psychological, medical, and language support services in collaboration with few nongovernmental organisations. ${ }^{12}$

Article 52 of the Law of Indonesia Number 21 Year 2007 on the Eradiction of the Criminal Act of Trafficking in Persons provides that the community or social organization may also establish shelters or trauma centres. Malaysia so far has not established any crisis centre specifically for human trafficking victims. Thus, establishing trauma centres is one of the best ways to provide more counselling, legal advice, and assistance needed by the victims. Trauma centres set up by nongovernmental organisations are preferable because many victims still fear Malaysian law enforcement officers. ${ }^{13}$

In the case of Public Prosecutor $v$ Lee Chin Chiew the Respondent was charged under Section 12 and 13 of ATIPSOM for trafficking 68 Indonesians. ${ }^{14}$ The Respondent faced 85 charges under Section 12 and 17 charges under Section 13 of ATIPSOM. On 27 October 2010, the Head of Immigration Department raided the Respondent's house and rescued 68 Indonesians who were in the custody of Respondent. All the rescued victims were given shelter at Bukit Ledang, Kuala Lumpur and an interim protection order was granted by the Court. 8 other rescued victims were safely repatriated to their own country. The Court of Appeal dismiss Prosecutor's appeal and upheld the Session Court decision which acquit Respondents from all 102 charges. In this case the prosecution failed to specify the act of exploitation by the Respondent.

In another case of Public Prosecutor $v$ Zhao Jingeng \& Ors the accused was arrested at the Kuala Lumpur International Airport by the Immigration Department and later charged for the offence of trafficking in persons under Section 12 of the ATIPSOM. ${ }^{15}$ The enforcement officer rescued 26 citizens of the Republic of China who were believed to be trafficking victims. Thereafter, an application for an interim protection order was made and granted to place the 26 trafficked victims in a place of refuge for 14 days for the purpose of carrying out an investigation and enquiry under Section 51 of the ATIPSOM.

11 M. Kumar. "Airline Cabin Crew Train to Spot Human Trafficking Victims”, (26 November 2017), online:https:/www.thestar.com.my/news/nation/2017/11/26/airline-cabin-crew-trainedto-spot-human-trafficking-victims/.

12 Maria Grazia Giammarinaro. "Report of the Special Rapporteur on trafficking in persons, especially women and children” (1 June 2015).

13 Lainey Weiss. "Trafficking in Malaysia: A Focus on Women and Children", (2017), online: http://www.wao.org.my/2017+WAO+Report+-

+Human+Trafficking+in+Malaysia_152_6_1.htm.

14 Public Prosecutor v Lee Chin Chiew, [2016] 1 LNS 1495.

15 Public Prosecutor v Zhao Jingeng \& Ors, [2010] 7 MLJ 306. 
At the expiry of the 14 days, a further application was made by the Investigating Officer of the Immigration Department to extend the interim protection order for three months in order to record the statement of the 26 victims. The issue raised in this case was whether the 26 rescued citizens of the Republic of China were "trafficked person" or not. The enforcement officer tendered a report in respect to all 26 victims. However, the Protection Officer only gave a report on 9 female victims; the remaining 17 male victims were left out. The report concluded that the Magistrate was erred by making an order under Section 51(3)(b)(ii) of the ATIPSOM. The High Court allowed the prosecution's revision application and made extension of protection order under Section 51(3)(a)(ii) of the ATIPSOM. The Judge found that the report of the Protection Officer is incomplete because there was no report on the remaining 17 male respondents. The report of Protection Officer on the nine female respondents informed the Magistrate that they were not trafficked persons.

The Judge further ordered that the 26 victims be placed at a place of refuge for a period not exceeding three months from 17 August 2009, to enable the enforcement officer to make the necessary deposition. The order given by the High Court is subject to any extension of the protection order of a foreign national that can be made upon application under Section 51(5) of the ATIPSOM. The Court also ordered the Immigration Department and the prosecution to take immediate steps under Section 52(1) of the ATIPSOM to record the evidence of the 26 victims. This is to ensure that there is no unnecessary prolonging of the stay of the 26 victims so that they can go back to their home country as soon as possible.

The above discussion shows that the trafficked victims once rescued will be placed in shelter or place of refuge in order to facilitate investigation and to ensure proper care and safety of the victims. Providing a shelter or place of refuge is a basic need fulfilled by the Malaysian government as per the international and regional law and through a Court's order. Courts, by granting interim protection order, allow the enforcement officer to take necessary action to build up the case against the accused person. If proper evidence is gathered by the enforcement officer during the protection period, victims will be repatriated to their home country as soon as possible. Malaysia, which has been characterized as a transit and destination country for human trafficking, provides this basic needs of protection of shelter or place of refuge for trafficking victims.

\section{APPOINTMENT OF PROTECTION OFFICER}

Appointing a Protection Officer is important to giving proper care and assistance to identified trafficking victims. Section $43{ }^{16}$ of ATIPSOM provides that Protection Officers may be appointed to have control over and responsibility for the care and protection of the trafficked person at the place of refuge. Upon order provided by the Magistrate or by direction of Minister, appointed Protection Officers have the ability to supervise the trafficked persons.

16 Anti-Trafficking in Persons and Anti-Smuggling of Migrants Act, 2007, s.43. 
Protection for identified or potential victims of trafficking is provided through interim protection orders orders issued by Magistrates. Identified or potential victims of trafficking are placed by enforcement officers in temporary custody and brought before a Magistrate within 24 hours. The interim protection order allows them to be housed in a shelter for 21 days while investigation is carried out. Based on the outcome of the inquiry of both the enforcement and the Protection Officer, the victim's status regarding the level of care and protection is determined by the Magistrate through a protection order.

In every human trafficking case, the report from the Protection Officer was of utmost importance. The report from Protection Officer would disclose the circumstances and activities of the subjects and whether the subjects were trafficked persons and whether they needed protection. If there was no report from the Protection Officer and investigating officer, the consideration of whether the subjects were traficked persons and needed protection would not be sufficiently evaluated.

In the case of Public Prosecutor v Nam Oithanhip, the Public Prosecutor appealed to the High Court in regards to the application of investigation officers on interim protection order made by Magistrate Court against 17 Thailand nationals. ${ }^{17}$ The Magistrate Court only relied on the report from Protection Officers which reported that the 17 rescued victims were not trafficked victims. The Magistrate Court only referred to the report of the Protection Officer without considering the report of the investigation officer which is required under section 51(3) of the Act. The Judge also held that in deciding whether a person is a trafficked person or otherwise under the ATIPSOM, the report of the investigation officer is more relevant as compared to the report of the Protection Officer. The Judge stated that looking at the division of duties and functions under Section 51(1)(a) and (b) of the Act, the Protection Officer is only required to investigate the background of the victim. The whole purpose of giving an interim protection order under Section 44(2) of the Act is for the purpose of carrying out an investigation and enquiry under Section 51 of the Act. This is to enable an enforcement officer to investigate the circumstances of the person's case for the purpose of determining whether the person is a trafficked person under the Act and a protection officer to enquire into the background of that person.

Considering reports submitted by the investigation officer and Protection Officer, the High Court granted 3 months of interim protection to the rescued victim in order for the investigation officer to conclude their investigation.

In the case of Public Prosecutor v Chap Jee \& Others four Burmese were arrested pursuant to the ATIPSOM. ${ }^{18}$ They were brought before the Magistrate Court and an interim protection order under Section 44(2) of ATIPSOM was granted. Thereupon, the investigating officer applied for a Protection Order under Section 51(3) of the Act and the Magistrate granted the order for three months. The High Court, pursuant to Section 323 of the Criminal Procedure Code called

17 Public Prosecutor v Nam Oithanhip, [2008] MLJU 297.

18 Public Prosecutor $v$ Chap Jee \& Others, [2010] 10 CLJ 621. 
for the record to examine the validity, correctness, and legality of the order and the regularity of the proceedings in respect of the four subjects.

Section 51 of the ATIPSOM required the investigating officer and the Protection Officer to prepare a report jointly and to present the report to the Magistrate during the application of the protection order. However, only the report from the Protection Officer was tendered during the application and no report was prepared by the investigating office. This is in spite of a 14 days interim protection order to investigate the circumstances of the subjects to determine whether they were trafficked persons under the Act.

In this case, the primary issue was whether the subjects were trafficked persons who were exploited and was in need of protection as prescribed under ATIPSOM. It was decided that the Magistrate was erred when he considered that he was satisfied that the subjects were trafficked persons and in need of protection although the report on that matter was never offered. The Magistrate only assumed that the subjects needed protection without scrutinising and examining the details of the report tendered by the Protection Officer. If the subject enters into Malaysia without travel document or permit, that does not automatically make them a victim or a trafficked person and should be protected. The object of the protection order is to protect the subject from being exploited. If from the investigation, the subject does not fall under the definition of trafficked person and only comes under the definition of illegal immigrants, then no protection order should be granted.

In the case of Public Prosecutor v Vira Prihatin \& Others a raid was conducted at Pusat Urutan Refleksologi Nico. ${ }^{19}$ The police managed to rescue all the individuals who were suspected to be trafficked person. In the course of investigation, the investigating officer applied for an interim protection order at the Magistrate Court Johor Bahru for a period of 21 days pursuant to Section 44(2) of ATIPSOM. The application was heard by a Senior Assistant Registrar who granted an interim protection order but for a duration of only 14 days. The Prosecutor filed an application for revision under Section 323 of the Criminal Procedure Code. There was no provision in Section 44 of the Act that allowed for an extended period of time beyond the 21 days. If a shorter period was allowed for the interim protection order and should the investigations not completed within that time, there was no recourse to seek for an extended period of time. Taken as a whole and reading in the proper context, the only reasonable construction therefore was that the stipulated 21 days period was meant to be mandatory. Any other construction would go against the intention of the legislature in requiring the investigation and enquiry to be completed within the stipulated period. To shorten what already might be an extremely short time frame for the authorities to investigate would be to defeat the purpose of the provision. Considering that, the High Court set aside the 14 days period imposed by the Magistrate and ordered the interim protection order to be for the stipulated period of 21 days.

19 Public Prosecutor v Vira Prihatin \& Others, [2018] 8 MLJ 421. 
In another case of Public Prosecutor $v$ Zhao Jingeng \& Ors the accused was arrested at the Kuala Lumpur International Airport by the Immigration Department and later charged for the offence of trafficking in persons under Section 12 of the ATIPSOM. ${ }^{20}$ The enforcement officer rescued 26 citizens of the Republic of China who were believed to be trafficking victims. Thereafter, an application for an interim protection order was made and granted to place the 26 trafficked victims in a place of refuge for 14 days for the purpose of carrying out an investigation and enquiry under Section 51 of the ATIPSOM.

At the expiry of the 14 days a further application was made by the investigating officer of the Immigration Department to extend the interim protection order for three months. The issue raised in this case was whether the 26 rescued citizens of the Republic of China were "trafficked person" or not. The enforcement officer tendered a report in respect of all the 26 victims and the Protection Officer only gave a report on 9 female victims and no report was made on the remaining 17 male victims. The judge found that the report of the protection officer was incomplete because of the missing male victims. The report of protection officer on the nine female respondents informed the Magistrate that they were not trafficked persons. The Judge in this case made reference to the case of Public Prosecutor $\mathrm{V}$ Nam Oithantip, where the Judge agreed that the report by the investigating officer is more relevant since such report is not about the background and personal information regarding the person but instead it is about whether such person is a trafficked person. However, in the present case there is nothing in the records to show that the Magistrate considered that report. The records show that the Magistrate made the order after considering only the report of the investigating officer.

It was decided that the Magistrate Court was incorrect in making an order under Section 51(3)(b)(ii) of the ATIPSOM. The High court allowed the prosecution's revision application and made extension of protection order under Section 51(3)(a)(ii) of the ATIPSOM. The Judge in this case going by the report of the investigationg officer, satisfied that the 26 respondents produced before him are trafficked persons and the order by the Magistrate should be made under section 51(3)(a)(ii) and not section 51(3)(b)(ii) of the Act.

It is important to distinguish that a protection order is not simply to protect persons who were not in need of protection and where no substantial activity lead to the offence of trafficking in person it is necessary to understand clearly the purpose of protection which is to save a person trapped in activities of trafficking a person. If the subject enters Malaysia without travel document or permit, that does not immediately categorize them as a victim or a trafficked person and should be protected. The object of the protection order is to protect the subject from being exploited or continuously exploited. If from the investigation, the subject does not fall under the definition of trafficked person and only comes under the definition of illegal immigrants, then no protection order should be granted. If the Magistrate found that the subjects are only illegal immigrants, they should not be placed at a 
protection home, but in an immigration depot waiting to be sent back to their countries or prosecuted. By ordering them to be placed under a protection home, it defeats the purpose of establishing the protection scheme itself, and the subjects instead of seeking employment or repatriation to their home countries- aretreated as illegal immigrants.Section 41A states: "This Part shall not apply to a smuggled migrant unless such smuggled migrant is a trafficked person.” Therefore, provisions of protection order do not apply to these four subjects as they were not trafficked person and protection order is set aside.

The scenario in the case of Siti Rashidah Razali \& Yang Lain $v$ Public Prosecutor is an example of a case where no exploitation was involved. ${ }^{21}$ In this case ten adults and three children were arrested in the house of Appellants because they did not have travel documents. From the statement of those subjects they came to Malaysia to look for a job and one of them came along with her three daughters to join her husband who has been working in Malaysia for some time. They were treated well by the Appellants. They were provided food, shelter, and were free to watch television and go outdoors. From the subjects' statement there was not evidence showing that they were exploited. Yet they are not interested im protection by the Malaysian authorities and instead prefernced employement opportunities and family reunification.

As stated before, appointing a Protection Officer in every trafficking case is essential. When a victim is rescued, a Protection Officer will be appointed in order to provide proper care. At the same time appointed Protection Officer need to prepare a report in determining whether the rescued person is a trafficked victim or not. The Court in granting protection order to the trafficked victim will study the report given by the Protection Officer and also the investigation officer. As such, appointment of Protection Officer in every case is vital for the proper care and protection of the identified victims. The whole process of protecting human trafficking victim might go wrong when a Protection Officer cannot or fails to precisley identify the victims.From the above discussion, there were cases in which Protection Officers have failed to do victim identification accurately. Thus, beyond simply providing an officer, providing training of Protection Officers is similarily important.

\section{MEDICAL TREATMENT}

Commonly, trafficking victims suffer from mental health issues, such as posttraumatic stress disorder (PTSD), anxiety, depression and other beahvioiral health issues. These problems originate from the fact that they are traumatised for a prolonged period during the trafficking process and have no control over their own lives. ${ }^{22}$ When a trafficking victim becomes sick while under the custody of the Government of Malaysia, it is extremely important to give medical treatment under

21 Siti Rashidah Razali \& Yang Lain v Public Prosecutor, [2011] 9 CLJ 459.

22 Lainey Weiss. "Trafficking in Malaysia: A Focus on Women and Children", (2017), online: http://www.wao.org.my/2017+WAO+Report+-

+Human+Trafficking+in+Malaysia_152_6_1.htm. 
the law of ATIPSOM and TIP Protocol. Article 6(3) of the TIP Protocol provides that the State Party shall assist the trafficked victims with medical, psycological, material assistance, and proper care. This also can be done with cooperation between non-governmental organisation, other relevant organisation, and other elements of civil society. ${ }^{23}$ Section 45 to 49 of ATIPSOM deals with the steps and procedures that should be taken by enforcement officers when a trafficked person needs medical examination and treatement.

In Indonesia, Article 51 to 54 of the Law of Indonesia Number 21 Year 2007 on the Eradiction of the Criminal Act of Trafficking in Persons provides for medical and social rehabilitation for the victims. A victim is entitled to receive medical and social rehabilitation, return assistance, and social reintegration from the government if such victim suffers physical and psychological hardship as a result of the criminal act by the traffickers. The Ministry of Health of Indonesia was responsible for funding victims' health care, which meant free healthcare by the national police hospitals. The Ministry of Health trained hospital personnel to provide health services to victims of trafficking and violence in 12 provinces in 2017, including physical and psychological treatment by trained paramedics and health service personnel at community health centers and hospitals. ${ }^{24}$

In the case of Public Prosecutor v Then Fook Khian, Robin Then Boon Leng, Then Boon Fui and Jointly trial with Public Prosecutor $v$ Then Fook Khian ${ }^{25}$ each of the accused persons faced 2 charges under Section 13 of ATIPSOM for an offence of trafficking two foreigners. During the criminal court proceeding, the first victim alleged that she was slapped, kicked, and was hit by rattan, a type of cane. She also claimed that one of the accused person injured her neck with a sword, causing bleeding. One issue raised by the defence in the course of proceeding is whether the first victim fit to plead and give her evidence in court. The investigating officer confirmed that she brought all the victims to Psychiatric Hospital, Hospital Mesra Bukit Padang Kota Kinabalu Sabah for treatment when the victims were sent to shelter home in Sabah. The reports were indeed confirmed by the hospital in question. The investigation officer also admitted that it is her duty to bring them to be examined by a specialist. The exhibit tendered in Court was stated that "patient (the first victim) [was] still complaining of auditory hallucinations which are commanding in nature". Dr. Leong Pooi Yee when asked about her understanding of "auditory hallucination" explained that auditory hallucination means patient can hear nonexistent people speaking The investigation officer also testified in Court that after several reference, counselling and examination to the hospital and taking of medication, the first victim is fit to give evidence and she can speak clearly.

23 Protocol to Prevent, Supress and Punish Trafficking in Persons, Especially Women and Children, supplementing The United Nations Convention Against Transnational Organized Crime, 2000, Article 6(3).

24 Trafficking In Persons Report, Indonesia, (2018), online: https://www.state.gov/j/tip/rls/tiprpt/ countries/2018/282673.htm.

25 Public Prosecutor v Then Fook Khian, Robin Then Boon Leng, Then Boon Fui and Jointly trial with Public Prosecutor v Then Fook Khian, [2012] 5 LNS 146. 
The above discussion demonstrates that when enforcement officers rescued victims and if the victims alleged that they were abused or ill-treated, the victims will be referred to hospital to get proper treatment and medication.. When identified trafficking victims fall sick in shelter or place of refuge, an immideate referral is to be made to nearby hospitals.

A standardized procedure should be maintained by the shelter or place of refuge, Protection Officer or enforcement officer for medical treatement. However, the Goverment of Malaysia may also consider adopting the Indonesian practice in setting up social rehabilatation centres in order to provide counselling session periodically to the trafficking victims so that traumatised victims are able to reintegrate with the society once repartriated.

\section{RIGHT TO WORK}

Trafficking victims should be given right to work before they are repatriated to their own countries. Article 6(3) of the TIP Protocol provides that each State Party shall consider employment, educational, and training oppurtunities for the trafficking victims. This right enunciated under Section 51A of the ATIPSOM provides that any person with an interim protection order has been granted, or any trafficked person to whom a protection order has been granted, may be given permission by the anti-trafficking council to be employed, engaged, or contracted with to work in any occupation during the period of the interim protection order. ${ }^{26}$ Section 66(2)(aa) provides that the anti-trafficking council needs to prescribe the qualifications, conditions, procedures or any other matters relating to the granting of permission to move freely and to work under Section 51A.

In the year of 2016, the Malaysian Government collaborated with an international hotel chain to identify employment opportunities for trafficking victims and advertised the said positions to more than 100 trafficking victims in government facilities. Only nine responded and four eventually took up the offer. As the process took extensive time, many victims may have lost interest. ${ }^{27}$ In 2017, 106 risk assessments of the 1,558 victims were identified conducted by the Government of Malaysia. Among these victims, only 6 victims were granted work visas and 12 special immigration passes for freedom of movement. ${ }^{28}$ The following year, 721 victims identified, and Malaysia granted two work visas and 91 special immigration passes for freedom of movement. Despite government efforts to provide lawful employment for victims, staff of government shelters reported that

26 Anti-Trafficking In Persons and Anti-Smuggling of Migrants Act, 2007, s.51A.

27 James Nayagam. "Human trafficking - an analysis of issues", (14 July 2016), online:http://www. freemalaysiatoday.com/category/opinion/comment/2016/07/14/human-trafficking-an-analysisof-issues.

28 Trafficking In Persons Report, Malaysia, (2017), online: https:/www.state.gov/j/tip/rls/tiprpt/ countries/2017/271235.htm. 
the majority of eligible participants declined to participate in the work program proposed by the government, quoting victims preferenced returning home. ${ }^{29}$

The complexity of the procedure and the lengthy process causes disinterest in victims towards accepting the work opportunity by the Government. Even Section $51 \mathrm{~A}$ is prerequisite for the approval of anti-trafficking council. Thus, Government of Malaysia should expedite the process and establish special, expedited procedures in approving the working visas for the trafficking victims. Jobs offered to the victims should be attentive to vast sectors in order to gain victims' interest in the working opportunity created by the Government.

\section{FREEDOM OF MOVEMENT}

Article 7 of the TIP Protocol provides for the status of victims of trafficking in persons in receiving States whereby each State Party shall consider adopting legislative or other appropriate measures that permit victims of trafficking in persons to remain in its territory, temporarily or permanently, in appropriate cases and each State Party shall give due consideration to humanitarian and compassionate factors. ${ }^{30}$ Amendment on ATIPSOM in the year of 2015 , created a process for shelter residents to move freely and to work if they are cleared by medical, security, and mental health professionals. They also should be approved by the anti-trafficking council, MAPO. ${ }^{31}$

In the year of 2018, the number of passes that isssued for freedom of movement increased from 12 passes to 91 passes. However, in practice, Malaysian authorities limit any movement of victims outside the shelter to occasional trips with a chaperone, two to three times a month. ${ }^{32}$ Thus, there is no absolute freedom of movement given to the victim for them to freely move around as per their willing.

\section{SAFE REPATRIATION}

Safe repatriation is another protection entitled by the human trafficking victims. They should be safely repatriated to their home country in order to reach family members and resume living their ordinary life in their own country. Article $8^{33}$ of the TIP Protocol provides for repatriation of victims of trafficking in persons. A State Party should consider a victim of trafficking in persons is a national or in which the person had the right of permanent residence at the time of entry into the

29 Trafficking In Persons Report, Malaysia, (2018), online: https://www.state.gov/j/tip/rls/tiprpt/countries/2018/282673.htm.

30 Protocol to Prevent, Supress and Punish Trafficking in Persons, Especially Women and Children, supplementing The United Nations Convention Against Transnational Organized Crime, 2000, Article 7.

31 Anti-Trafficking In Persons and Anti-Smuggling of Migrants Act, 2007, ss 51A, 66(2) (aa).

32 Trafficking In Persons Report, Malaysia, (2018), online: https:/www.state.gov/j/tip/rls/tiprpt/countries/2018/282673.htm.

33 Protocol to Prevent, Supress and Punish Trafficking in Persons, Especially Women and Children, supplementing The United Nations Convention Against Transnational Organized Crime, 2000, Article 8. 
territory of the receiving country. A State Party also shall facilitate and accept, with due regard for the safety of that person, the return of the victim without undue or unreasonable delay. This provision also facilitates the return of a victim of trafficking without proper documentation to ensure the victim had the right of permanent residence at the time of entry into the territory of the receiving State. In the meantime, State Party shall agree to issue such as travel documents or other authorisation as may be necessary to enable the person to travel to and re-enter its territory.

Section 54 of ATIPSOM provides for release of trafficked person. Upon revocation of protection order or expiry of the period specified in a protection order, the Immigration Officer shall take all the necessary steps to facilitate the return of that trafficked person to his / her country of origin without unnecessary delay. In the past, Malaysia has co-operated with the embassies of some of the largest sending countries to record legal statements from trafficking victims and allowed the victims to return to their country of origin before the end of the legal proceedings in courts when outstanding legal issues, such as repayment of back wages, were resolved. ${ }^{34}$

For instance, in the case of Asha, ${ }^{35}$ she was confined by her employer in a house and abused with no food or water provided. With the help of her neighbour, police rescued her. She was brought to the hospital for medical check-up and referred to the Indian High Commission. The Indian High Commission brought Asha to Women Aid Organisation to access the shelter services while she was awaiting repatriation to India. She also had expressed her desire to take up a case against her perpetrators under the ATIPSOM. She returned to India while the criminal court proceedings against traffickers were still in progress.

In the case of Public Prosecutor $v$ Lee Chin Chiew ${ }^{36}$ the Respondent was charged under Section 12 and 13 of ATIPSOM for trafficking 68 Indonesians. All the rescued victims were placed at a shelter in Bukit Ledang, Kuala Lumpur, and an interim protection order was granted by the Court. Another 8 of the rescued victims were safely repatriated to their own country as there is no concrete evidence that they were trafficked.

In another case of Public Prosecutor $v$ Zhao Jingeng \& Ors ${ }^{37}$ the Judge further ordered that the 26 respondents be placed in a place of refuge for a period not exceeding three months from 17 August 2009, to enable the enforcement officer to make the necessary application under Section 52 of the ATIPSOM for the recording of their deposition or evidence before a Magistrate. The order given by the High Court is subject to any extension of the protection order of a foreign national that can be made upon application under Section 51(5) of the ATIPSOM.

34 Trafficking In Persons Report, Malaysia, (2018), online: https://www.state.gov/j/tip/rls/tiprpt/countries/2018/282673.htm.

35 Lainey Weiss. "Trafficking in Malaysia: A Focus on Women and Children”, (2017), online: http://www.wao.org.my/2017+WAO+Report+-

+Human+Trafficking+in+Malaysia_152_6_1.htm.

36 Public Prosecutor v Lee Chin Chiew, [2016] 1 LNS 1495.

37 Public Prosecutor v Zhao Jingeng \& Ors, [2010] 7 MLJ 306. 
The Court also held that the Immigration Department and the prosecution to take immediate steps under Section 52(1) of the ATIPSOM to record the evidence of the 26 Respondents. This is to ensure that there is no unnecessary prolonging of the stay of the 26 Respondents so that they can go back to their home country as soon as possible.

The discussion above shows that most of the victims of trafficking in person in Malaysia were safely repatriated to their country of origin without undue delay once investigation completed by the enforment officers. The victims may also decide to stay here during the trial process against the traffickers.

\section{CONCLUSION}

The Government of Malaysia has increased the efforts to prevent trafficking and to protect the victim of human trafficking in Malaysia. It has enacted ATIPSOM 2007 which aims to exterminate trafficking in persons into Malaysia. A thorough analsysi of this charter revelas that the provisions of the ATIPSOM 2007 are compatible to the international instruments, especially the TIP Protocol. Identification of victims of human trafficking is utmost important under the ATIPSOM 2007. In any event, if the investigation officer submits a report which mislead the Court while determining the protection order should be granted or not, the real victim will suffer great violation of human rights. A human right centred in identifying the victim should be established to approach early identification and assistance to victims of human trafficking. Identification of human trafficking victims are crucial to ensure both the protection of the rights of trafficked persons, and successful prosecution of the traffickers.

However, in the absence of factual evidence that indicates trafficking crime (which may be difficult to obtain at an early stage of investigation), the Malaysian authority may be unwilling to treat the person concerned as a victim. Considering the difficulties involved in proving the crime of trafficking and the time needed to establish all the facts of a case, it is recommended that Malaysia's authority give the benefit of the doubt to a person claiming that he or she is subjected to severe exploitation. Relatedly, these "tentative" victims should be able to enjoy the same protection as the identified victim.

There are many barriers for victims to come forward such as fear of revenge harm against them or their children or families, fear for deportation, or the situation of dependency in which they find themselves. Therefore, Malaysia should enhance a pro-active approach to identification, which is especially important for child victims, and strengthen policy aimed at empowering trafficked persons and encouraging them to come forward and denounce exploitation. Thus, the early stage of identification of human trafficking victim is important in order to protect the victim under the enacted law.

In conclusion, Malaysia should enhance and continue the development of regional guidelines related to caring for trafficking survivors, in light of national and bilateral guidelines, and also by strengthening coordination partnership, and 
international cooperation and implement effectively the relevant existing guidelines. The victim shall be identified effectively in order to ensure the protection under the enacted law. Based on discussions in this paper, Malaysia has adopted most of the fundamental aspects of victims' protections and care as specified by international and regional standards and Malaysian law. However, there are some areas of improvement which include training of Protection Officer, continuous counselling sessions and extended freedom of movement for trafficked victims and establishement of social rehabilitation centres.

Acknowledgement - this research is funded by a research fund from the Ministry of Higher Education of Malaysia: FRGS/1/2017/SSI10/UKM/02/6.

\section{BIBLIOGRAPHY}

A. Ibrahim Almutaqqi. "ASEAN Briefs, Fighting For Freedom: Combatting Human Trafficking in ASEAN", (April 2017).

Anti-Trafficking In Persons and Anti-Smuggling of Migrants Act (2007).

Convention on the Elimination of All Forms of Discrimination Against Women (1979).

Convention on the Rights of Child (1989).

James Nayagam. "Human trafficking - an analysis of issues", (14 July 2016), online:http://www.freemalaysiatoday.com/category/opinion/comment/2016/07/ 14/human-trafficking-an-analysis-of-issues.

Janita Kan. "Malaysia Commits to Combating Human Trafficking after US Report", (2 July 2018), online: https://www.theepochtimes. com/malaysia-commits-tocombating-human-trafficking-afterusreport_2580760.html.

Lainey Weiss. "Trafficking in Malaysia: A Focus on Women and Children", (2017), online: http://www.wao.org.my/2017+WAO+Report+-+Human+ Trafficking +in+Malaysia_152_6_1.htm.

M. Kumar. “Airline Cabin Crew Train to Spot Human Trafficking Victims”,(26 November 2017), https:/www.thestar.com.my/news/nation/2017 /11/26/airlinecabin-crew-trained-to-spot-human-trafficking-victims/.

Maria Grazia Giammarinaro. Report of the Special Rapporteur on trafficking in persons, especially women and children (1 June 2015).

Maya Fachrani Faisal, Selvi Supramaniam, Child Protection System In Malaysia An Analysis of the System for Prevention and Response to Abuse, Violence and Exploitation against Children (Ministry of Women, Family and Community Development and UNICEF Malaysia, 2013).

Protocol to Prevent, Supress and Punish Trafficking in Persons, Especially Women and Children, supplementing The United Nations Convention Against Transnational Organized Crime (2000). 
Ruth Rosenberg. "Trafficking Women and Children in Indonesia”, (US Agency for International Development).

Suhana Saad. Ali Salman. "Government Policy and the Challenge of Eradicating Human Trafficking in Malaysia”, (2014).

Supt.P.R Gunarajan A/L Ramayal. "Organised Crime: Governments Initiatives, Laws and Investigation of Human Trafficking In Person and Smuggling of Migrants in Malaysia”, (9 July 2013).

Trafficking in Persons Report, Indonesia, (2018), online: https:/www.state.gov/j/ tip/rls/tiprpt/ countries/2018/282673.htm.

Trafficking in Persons Report, Malaysia, (2015), online: http://www.state.gov/j /tip/rls/tiprpt/2015/243366.htm.

Trafficking in Persons Report, Malaysia, (2017), online: https:/www.state.gov/j /tip/rls/tiprpt/countries/2017/271235.htm.

Trafficking in Persons Report, Malaysia, (2018), online: https://www.state.gov/j /tip/rls/tiprpt/countries/2018/282673.htm.

Rohaida Nordin is an Associate Professor at Faculty of Law, the National University of Malaysia. She is the Head for postgraduate programme at the Faculty. Her area of specialization is international human rights law especially the rights of indigenous peoples, asylum seekers and refugees and other vulnerable groups. She is the Head for Human Rights and Humanitarian Unit of the Centre of International Law and Syiar (CILAS).

Renuka a/p Jeyabalan is a Legal Officer at Enfocement Agency Integrity Commission, Malaysia. She was a former postgraduate student of Faculty of Law, National University of Malaysia. 